\title{
Звезды аналитического приборостроения Ричард Перкин и Чарлз Элмер
}

PerkinEllmer For the Better

\section{Ю.А. Золотов}

\begin{abstract}
Мы продолжаем публикацию кратких биографий создателей крупнейших фирм, разрабатывающих и выпускающих аналитические приборы. В основе - материалы, подготовленные Американским Фондом химического наследия (Chemical Heritage Foundation) и предложенные вниманию участников одной из Питтсбурских конференций по аналитической химии и прикладной спектроскопии (Pittcon)".
\end{abstract}

\section{Чарлз Уэсли Элмер}

Чарлз Элмер (1872-1954), как и его партнер Ричард Перкин, родился в Нью-Йорке и большую часть своей жизни работал судебным репортером. Большой любитель наблюдать звезды, Ч. Элмер был уже близок к отставке, когда в 1936 году он выступил на астрономическом семинаре в Бруклине. В зале оказался Ричард Перкин. Познакомившись, оба посетовали на отсутствие в США производства хороших оптических приборов и тут же договорились решить эту проблему. Начиная с капитала в 20 тыс. долл. (75\% - Р. Перкина, остальные внес Ч. Элмер), партнеры учредили в НьюЙорке фирму PerkinElmer - оптическое предприятие и начали импортировать приборы из Европы.

Вскоре компания стала налаживать собственное производство. Чарльзу нравилось работать в мастерской, а организационные дела он предоставил Ричарду, природным талантом которого была торговля. Однако Ч. Элмер был казначеем и вообще основным финансистом компании. Поддерживая взаимный интерес к астрономии, компаньоны участвовали, насколько могли, в каждом астрономическом симпозиуме и семинаре, часто преодолевая сотни миль ради одного мероприятия. Компания PerkinElmer откликнулась на вызовы, брошенные Второй мировой войной, расширяя производство такого жизненно важного оборудования, как прицелы для бомбометания и приборы, определяющие расстояние до самолета. Между тем Ч. Элмер так выстроил научно-исследовательскую и опытно-конструкторскую структуру компании, что после войны она без труда перешла на гражданскую

* Статья из кн. Ю. А. Золотова «Очерки истории аналитической химии" (М.: ТЕХНОСФЕРА, 2018) публикуется с изменениями и дополнениями. продукцию. Оставаясь верной своим истокам, фирма создала 33-дюймовый телескоп "Бейкер Шмидт", который был установлен Гарвардским университетом в 1950 году в Южной Африке. Спустя пять лет и через год после кончины Ч. Элмера компания установила поперечную панорамную фотокамеру размером 12×14 футов, которая могла делать точные снимки для воздушной разведки от горизонта до горизонта, начиная с 40 тыс. футов. Это было значительное достижение доспутниковой фотографии.

В честь Чарльза назван небольшой лунный кратер Элмер, который расположен к югу от Моря Смита, недалеко от восточного лимба Луны. В Гарвардской обсерватории 1 декабря 1978 года был открыт астероид, названный 2493 Elmer в память о Чарльзе Уэсли Элмере, чья встреча с Ричардом С. Перкиным на праздновании 300-летия Гарварда в 1936 году привела к созданию корпорации PerkinElmer два года спустя. Будучи директором астрономического факультета Бруклин ${ }^{-}$ ской академии искусств и наук, он основал Ассоциацию

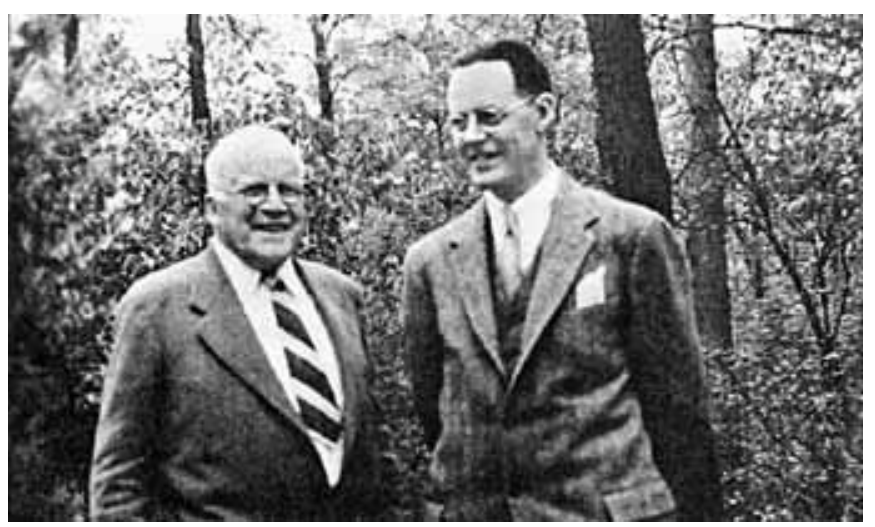

Чарльз Элмер и Ричард Перкин 
астрономов-любителей в Нью-Йорке и Институт Кастера в Саутхолде (Лонг-Айленд), а его летняя резиденция долго служила хранилищем телескопов для астрономов-любителей.

\section{Ричард Скотт Перкин}

Ричард Перкин (1906-1969) с детства интересовался астрономией, в одиннадцатилетнем возрасте сам мастерил телескопы, в тринадцать шлифовал и полировал линзы. После школы учился в колледже, где изучал химическую технологию, а затем начал трудовую жизнь в брокерской конторе на Уолл-стрит. Банковская карьера Ричарда закончилась, когда он познакомился с Чарльзом Элмером.

Ч. Элмер читал лекции по астрономии в Бруклинском колледже, слушателем которых был Р.Перкин. Их общий интерес к изучению звезд привел к идее начать совместный бизнес в сфере прецизионной оптики. Даже столкнувшись во время Первой мировой с проблемой поставок, Соединенные Штаты все еще не очень основательно относились к производству точных оптических приборов. В 1937 году Р. Перкин и Ч. Элмер создали партнерство по импорту таких приборов из Европы, но через двенадцать месяцев компания сама стала выпускать оптические компоненты в Джерси-сити (штат Нью-Джерси). Когда же началась Вторая мировая война, компания PerkinElmer смогла занять важное место на рынке военных заказов, поскольку поставки из Европы, прежде всего из Германии, теперь были заблокированы. Компания расширяла производство, делая фотоаппараты, перископы, дальномеры, устройства для точного бомбометания и другие оптические приборы. В 1942 году PerkinElmer стала первой в стране компанией в сфере оптической техники, руководство военно-морского флота отметило ее как "центр превосходства".

После 1945 года Р. Перкин начал развивать в компании новое направление - обновление и производство инфракрасных спектрометров. Было налажено производство первого в мире коммерческого варианта инфракрасного спектрометра - Model 12 IR Spectrometer. Texнологии, впервые примененные в этой модели, до сих пор являются основным инструментом химического анализа. Они и позволили компании выйти в ряды основных поставщиков аналитического оборудования. Эти приборы стали покупать университеты и учреждения здравоохранения. В 1950-х годах компания стала разрабатывать и производить газовые хроматографы и атомно-абсорбционные спектрометры, которые открыли новую эпоху аналитических лабораторных операций. В 1955 году стартовало производство первого американского коммерческого газового хроматографа "Модель 154». В 1957 году на конференции в Питтсбурге компания PerkinElmer представила

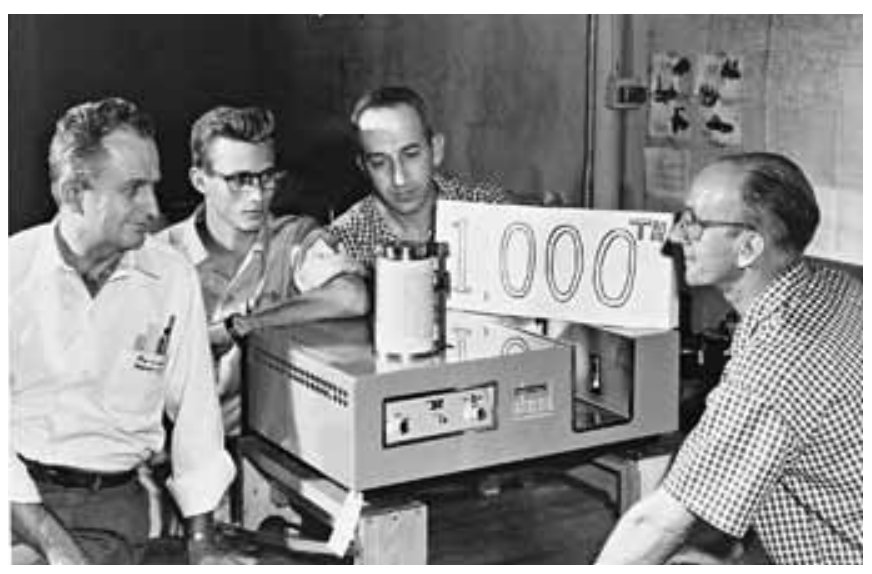

Легендарная модель 60-х годов -

Perkin-Elmer Model 137 Infracord Spectrophotometer

первый коммерческий двухлучевой инфракрасный анализатор, предназначенный для широкого использования, - Infracod Model 137. В 60-х основано собственное производство в Западной Германии и Великобритании. Р. Перкин считал, что компания должна оставаться на острие инструментальных технологий и создавать приборы, которые соответствовали бы достижениям в таких областях, как атомная энергетика, твердотельная электроника, лазеры или биофизические исследования. К концу жизни Р. Перкина компания значительно расширила список производимых изделий. Поддерживая давний интерес основателя компании к астрономии, в перечень продукции были включены разнообразные высокотехнологичные устройства, в том числе лазерные приборы, используемые на спутниках. Отделение оптических приборов изготовило тонкое прозрачное золотое покрытие для окошка шлема Нила Армстронга (шлем был использован во время посадки на Луну корабля "Аполлон-11"), а в 1976 году - созданный в компании масс-спектрометр достиг Марса на посадочном модуле "Викинг» НАСА.

В честь Ричарда назван кратер Перкин (лат. Perkin)крупный древний ударный кратер в северном полушарии обратной стороны Луны. Название утверждено Международным астрономическим союзом в 1970 году.

Динамично развиваясь и осваивая новые направления, на сегодняшний день компания PerkinElmer заняла прочные лидирующие позиции в нескольких отраслях, это научные исследования в области фармацевтики и генетики, аналитическое оборудование для медицинских и научно-исследовательских лабораторий, оптоэлектроника. PerkinElmer создает новые решения для медицины, телекоммуникаций и любой отрасли, где необходимо высокоскоростное прецизионное оборудование. 